Babeş-Bolyai

University

Cluj-Napoca

\title{
TRANSYLVANAN REVIEW
}

\section{OF ADMINISTRATIVE SCIENCES}


Authors must send one electronic copy to Cristina Mora (cristina@rtsa.ro)

Submission of a manuscript will be held to imply that it contains original unpublished work and is not being submitted for publication elsewhere at the same time.

The language of the journal is Romanian (when the use of diacriticals is required) or an international language (English, French, German, Italian, Spanish, etc.). All submissions must have a title, be 1,5 lines spaced, have a margin of $2 \mathrm{~cm}$ all round, be between 7 and 25 pages long, be written in Times New Roman Style, have 12 points characters, and must start with an alignment.

- The title page must list the full title, short title of up to 70 characters, names and affiliations of all authors, their qualifications, their post and their current appointment if different. Give the full address, including email, telephone and fax, of the author who is to check the proofs.

- Supply a long structured abstract written in English, of up to 200 words for all articles (except book reviews). This is to enable readers, to get a comprehensive picture of the main issues of the study and its impli-cations without reference to the text. The authors are requested to summarize very clearly the contents and implications of their study, following properly the structure of the different subsections:

Background, Aims of the Study, methods, Results, Discussion (with limitations of the study), Implications for Policies, Implications for Further Research) on the basis of the particular features of their article, in order to enable the readers of different cultural backgrounds and countries to easily follow the main issues of the study. It should contain no citation to other published work.
TEXT

\section{Abbreviations}

All abbreviations should be written in full the first time they appear. Mathematical symbols may be either handwritten or typewritten. Greek letters and unusual symbols should be identified separately in the margin. Distinction should be made between capital and lower case letters; between the letter $\mathrm{O}$ and zero; between the letter 1 and the number one and prime; between $\mathrm{K}$ and Kappa.

\section{REFERENCE STYLE}

References should be provided either in Harvard or Chicago manual style.

All references must be complete and accurate. Online citations should include date of access. If necessary, cite unpublished or personal work in the text but do not include it in the reference list.

\section{FURTHER INFORMATION}

Proofs will be sent to the author for checking. This stage is to be used only to correct errors that may have been introduced during the production process. Prompt return of the corrected proofs, preferably within two days of receipt, will minimise the risk of the paper being held over to a later issue.

\section{LETTERS TO EDITORS}

This section is aimed at encouraging a lively interaction between readers, authors, editorial board and publisher. Letters should refer to articles published in the journal. They should not exceed 500 words and there should be no more than five references. Letters will be edited for clarity and conformity with Transylvanian Review of Administrative Sciences style, and may be shortened. Proofs will not be sent to authors.

\section{BOOK REVIEWS}

The journal will publish both book reviews and lists of new book titles considered of relevance for those interested in public administration. 


\title{
Transylvanian Review of Administrative Sciences
}

\author{
No. 58 官 / (O)ctober / 2019
}

\author{
Senior Editor: Călin Emilian Hinţea \\ Director: Ciprian Tripon \\ Editor: Cristina Mora \\ Administrative director: Ovidiu Boldor \\ Editorial Board: Balogh Marton, Daniel Buda, Marius Dodu, Dacian Dragoş, Călin Ghiolţan \\ Veronica Junjan, Dan Lazăr, Elena Minea, Natalia Negrea, Liviu Radu, Sorin Dan \\ Şandor, Bogdana Neamţu, Bianca Radu, Raluca Gârboan, Adrian Hudrea, Cornelia \\ Macarie, Dan Balica, Tudor Ticlău, Cristina Haruţa, Horia Raboca, Raluca Suciu, Ana \\ Elena Ranta, Octavian Moldovan, Alexandru Pavel
}

\section{INTERNATIONAL ADVISORY BOARD}

Carole NEVES, Smithsonian Institute, Washington, DC

Allan ROSENBAUM, Florida International University

Arno LOESSNER, University of Delaware

Roger HAMLIN, Michigan State University

Laszlo VARADI, Corvinus University of Budapest

Eric STRAUSS, Michigan State University

Gyorgy JENEI, Corvinus University of Budapest

Adriano GIOVANNELLI, Genoa University

Bernadine Van GRAMBERG, Victoria University

Julian TEICHER, Monash University

Geert BOUCKAERT, Catholic University of Leuven

Veronica JUNJAN, University of Twente

György HAJNAL, Corvinus University of Budapest

Taco BRANDSEN, Radboud University Nijmegen, Secretary-General of the European Association for Public Administration Accreditation (EAPAA)

Juraj NEMEC, Masaryk University, president of The Network of Institutes and Schools of Public Administration in Central and Eastern Europe (Nispacee)

Maria ARISTIGUETA, University of Delaware

Yüksel DEMIRKAYA, Marmara University

Marian PREDA, University of Bucharest

Marius PROFIROIU, Bucharest Academy of Economic Studies

Alexander HENDERSON, Long Island University

Gregory PORUMBESCU, Northern Illinois University 
Transylvanian Review of Administrative Sciences has been selected for coverage in Thomson Reuters products and custom information services. Beginning with no. 22E/2008, this publication is indexed and abstracted in the following:

1. Social Sciences Citation index®

2. Social Scisearch ${ }^{\circledR}$

3. Journal Citation Report/Social Sciences Edition

Transylvanian Review of Administrative Sciences is also listed in EBSCO, IBSS - International Bibliography of Social Sciences, Elsevier Bibliographic Databases, PA@BABEL Public Administration's dataBase for Accessing academic publications in European Languages and DOAJ - Directory of open access journals. 


\section{CONTENTS}

Mojca BIŠČAK

Jože BENČINA

5 The Impact of HRM Practices on the Performance of Municipalities.

The Case of Slovenia

Oana Maria BLAGA

Răzvan Mircea CHERECHEȘ

Cătălin Ovidiu BABA

24 A Community-Based Intervention for Increasing Access

to Health Information in Rural Settings

Emil BOC

38 The Development of Participatory Budgeting Processes in Cluj-Napoca

Andrei CHIRCĂ

Dan Tudor LAZĂR

52 Students's Visitors - Among the Unexplored Types of Local Tourism?

Min-Hyu KIM

65 Factors Influencing the Propensity to Contract Out Health and Human Services in Response to Government Cutbacks: Evidence from US Counties

Mateusz LEWANDOWSKI

85 Organizational Drivers of Performance Information Use:

The Perspective of Polish Local Governments

Romea MANOJLOVIĆ TOMAN

Goranka LALIĆ NOVAK

100 The (Lack Of) Demand for Performance Information by the Croatian Parliament Oleksiy POLUNIN

116 The Case of Ukrainian Corruption: Phenomenology and Psychological Insides 
DOI:10.24193/tras.58E.6

Published First Online: 10/15/2019

\section{ORGANIZATIONAL DRIVERS \\ OF PERFORMANCE INFORMATION \\ USE: THE PERSPECTIVE OF POLISH \\ LOCAL GOVERNMENTS*}

\section{Mateusz LEWANDOWSKI}

\author{
Mateusz LEWANDOWSKI \\ $\mathrm{PhD}$, Deputy Head of the Institute of Public Affairs, \\ Faculty of Management and Social Communication, \\ Jagiellonian University, Kraków, Poland \\ Tel.: 0048-12-664.58.30 \\ E-mail: mateusz.lewandowski@uj.edu.pl
}

Acknowledgement. This work was supported by the National Science Center, Poland, under Grant no. 2016/21/D/ HS4/00716. 


\section{Introduction}

The New Public Management reforms fostered the implementation of performance management systems all around the world, also in Central-Eastern European countries. The main product of such systems is performance information (PI), provided in order to facilitate public managers and policymakers in decision-making, resource allocation, etc. (Van Dooren, Bouckaert and Halligan, 2015). Although for the last 40 years profound knowledge on public sector performance management has been gathered (Pollitt, 2018), its practical application and use often remained an 'Achilles heel' of public administration (Bouckaert and Peters, 2002; Moynihan and Pandey, 2010; Cepiku et al., 2017), also in CEE countries (Nemec, 2010; Fundacja Rozwoju Demokracji Lokalnej, 2013).

A substantial amount of research has focused on the following main areas of performance information use: the conditions affecting the process of its adoption; the implementation of performance measurement systems (Niven, 2003); the factors influencing the use of performance information (De Lancer-Julnes and Holzer, 2001); the assessment of performance in municipalities; the effects of this use (Beeri, Uster and Vigoda-Gadot, 2018); and its misuse and dysfunctional use (Bouckaert and Balk, 1991). This study focuses on the drivers and antecedents of the use of performance information. Within this vein, various factors have been tested since De Lancer-Julnes and Holzer (2001) published their seminal paper outlining a theory of utilization of performance information, which revealed the impact of rational and cultural factors on performance information use. More recently, Kroll (2015), on the basis of a thorough review of empirical investigations, provided a list of individual, organizational, and environmental factors, classified according to the strength of the impact on the use of PI. Simultaneously, he advocated studying indirect effects of independent factors on PI use in order to reach 'a better (stepwise) understanding of the mechanisms behind direct effects' (Kroll, 2015, p. 477). One way to follow this direction is to verify direct relations between known drivers of the use of performance information.

In accordance with the indicated research gap, this paper focuses on organizational drivers of performance information use because it is more difficult and risky to implement performance management in post-communist countries (Nemec, Merickova and Ochrana, 2008). By building on the Information Systems theory, this study contributes to the Performance Information Utilization theory by proposing decoupling the major and most influential organizational driver of performance information use, and by testing the relations between these decoupled components, namely the quality and usefulness of performance information, and organizational capabilities consisting of other important organizational drivers of PI use indicated by Kroll (2015). Considering that most empirical studies on the antecedents of the use of performance information have been conducted in the USA and Germany, this paper contributes to the debate not only by providing a more in-depth understanding of the relations between the organizational drivers of PI use, but also by embracing the neglected political context of Central Eastern European countries. 
This article is structured as follows. First, the results of a literature review on the organizational drivers of performance information use are reported in order to complement Kroll's (2015) findings and get the most up-to-date knowledge in this field. Second, two theories of information systems and information quality are used to develop a theoretical framework of the relations between the most important organizational drivers of PI use. Then, the methodology section describes the sample, measures, and procedures. Next, the results are presented and discussed. Finally, some conclusions and implications for practice are drawn.

\section{Organizational drivers of performance information use}

The use of performance information was scrutinized from various perspectives. De Lancer-Julnes and Holzer (2001) distinguished as two separate stages the adoption and the implementation of performance information. The adoption phase pertains to the development of outputs, outcomes, and efficiency measures. In turn, the implementation phase denotes the actual use of performance measures in management and in reporting (De Lancer-Julnes and Holzer, 2001, p. 695). Other studies outlined over forty different practical applications (e.g., allocation of resources, organizational development), encapsulated in several main types of use, for example steering and control, learning, and giving account (Behn, 2003; Van Dooren, Bouckaert and Halligan, 2015). Although such an understanding of performance information utilization has been widely recognized (Heinrich, 1999; Moynihan and Pandey, 2010; Kroll and Moynihan, 2015), it is not the only one. For example, Dooren (2005) speaks about supply (production) and demand (use) of performance information, defined as 'having performance measurement tools' and 'doing performance measurement', respectively (Van Dooren, 2005, p. 369). Empirical evidence supports this distinction because performance information is not always incorporated in decision-making, reporting or organizational learning, even though it is collected and provided with a well-designed performance measurement system (Angiola and Bianchi, 2015; Cepiku et al., 2017).

Public sector performance management literature has identified various organizational factors affecting the use of performance information. In general, the use of performance information is contingent on the design of the performance management system (Heinrich, 1999). This view was extended in the seminal paper of De Lancer-Julnes and Holzer (2001), who identified different technical/rational and political/cultural factors influencing the adoption and implementation (use) of PI. For the adoption phase of PI utilization, organizational capabilities were defined as organizational readiness to deploy and sustain a performance management system (Van Dooren, Bouckaert and Halligan, 2015). In practice, specific sets of organizational requirements needed to implement a particular system were defined, like the Balanced Scorecard (Niven, 2003) or executive control (INTOSAI, 2004; European Commission, 2007; COSO, 2013). However, De Lancer-Julnes and Holzer's (2001) study showed that resources, goal orientation, information, and internal requirements are important factors affecting the implementation of PI if the adoption phase is excluded from 
the model. When the adoption phase is included, only the resources and information remained statistically significant. The use of performance information requires dedicated staff and organizational structure, data collection, access to 'how-to' information, and monetary incentives (De Lancer-Julnes and Holzer, 2001). On the contrary, Kroll and Vogel (2014)argued that public managers driven by a public service motivation and working under transformational supervisors are more likely to use PI. Van Dooren (2005), in turn, found that the measurability of output, the size of organizations, and the goal affect the way in which performance measurements are defined and gathered. Usually, bigger organizations have more resources with which to implement information systems and put greater demands on such performance information. A lower ability to measure output, as in diplomacy or cultural services, might naturally hinder PI use, while goal orientation should enhance it (Van Dooren, 2005).

A recent systematic literature review of empirical investigations of the antecedents and drivers of performance information use revealed the most important organizational drivers, such as measurement system maturity, leadership support, support capacity, innovative culture, and goal orientation/clarity (Kroll, 2015). As promising organizational drivers, the same study identified learning forums and routines, attitudes toward performance measures, prosocial motivation, and networking behavior (Kroll, 2015). The latest studies, summarized in Table 1, enrich the picture drawn by Kroll (2015).

Table 1: Organizational drivers of performance information use

\begin{tabular}{|c|c|c|c|c|c|}
\hline Sources & Country & $\begin{array}{c}\text { Level of } \\
\text { government }\end{array}$ & Method & Sample & Organizational drivers of PI use \\
\hline Angiola and Bianchi, 2015 & Italy & local & quantitative & $n=31$ & $\begin{array}{l}\text { Managers' competences (public managers' } \\
\text { skills in the use of performance measures) } \\
\text { Quality of data } \\
\text { Managerial decisional flexibility }\end{array}$ \\
\hline $\begin{array}{l}\text { Henderson and } \\
\text { Bromberg, } 2015\end{array}$ & USA & local & quantitative & $n=564$ & $\begin{array}{l}\text { Information availability } \\
\text { Relationship length }\end{array}$ \\
\hline Moynihan, 2015 & USA & $\begin{array}{l}\text { local } \\
\text { (county) }\end{array}$ & $\begin{array}{l}\text { quantitative } \\
\text { (experiment) }\end{array}$ & $n=140$ & $\begin{array}{l}\text { Advocacy (positive comments from } \\
\text { a public employee about performance) } \\
\text { Goal ambiguity }\end{array}$ \\
\hline Lee and Clerkin, 2017 & USA & none (NGO) & quantitative & $n=259$ & $\begin{array}{l}\text { Risk aversion } \\
\text { Political capacity }\end{array}$ \\
\hline Cepiku et al., 2017 & Italy & national & qualitative & 2 cases & $\begin{array}{l}\text { Involvement of employees } \\
\text { and other internal stakeholders } \\
\text { Accessibility and quality of their contents } \\
\text { Adequacy of competencies and time for an- } \\
\text { alyzing and using performance information } \\
\text { Organizational culture } \\
\text { Consistency of (other) operative systems } \\
\text { Organizational structure } \\
\text { (level of individual autonomy) }\end{array}$ \\
\hline
\end{tabular}

Source: Based on author's review of indicated sources. 
In particular, these papers help to describe better the variety of contexts of PI use, confirm some previously known drivers of PI use, and indicate some new ones. Henderson and Bromberg (2015) found that longer relationships with an agency are related negatively and significantly to performance information use, although the magnitude of the effect was small. If an agency is socially embedded and demonstrates a continual history of service provision, the municipal officials have less need to rely on performance measures when assessing such an agency (Henderson and Bromberg, 2015). Moynihan's (2015) study revealed that positive comments from public employees about performance can alter the budget allocation for a program, and resource allocations are lower due to goal ambiguity and disconfirmation of expectations created by performance targets. Lee and Clerkin (2017) examined NGOs and found that political capacity and risk aversion are significant factors affecting the use of outcome information. The ability to convince stakeholders and to obtain their support depends to some extent on using the information embracing organizations' outcomes. In turn, lower risk aversion leads to higher willingness to engage in organizational change, which leads to improvements in decision-making through the use of performance measures (Lee and Clerkin, 2017).

The most recent literature does not affect the main conclusions regarding the organizational drivers of performance information use, derived from Kroll's (2015) study. Although it helps to understand better the variety of drivers of PI use, it does not contribute to current knowledge on the mediating and moderating effects between drivers. Because looking for the indirect effects between the drivers of PI use assumes the existence of relations between them, this study focuses on the relations between the most influential organizational drivers according to Kroll's findings (2015).

\section{Hypothesis development}

Among the influential organizational factors, many researchers reported the maturity of the measurement system as the most important driver of PI use (De Lancer-Julnes and Holzer, 2001; Melkers and Willoughby, 2005; Kroll and Vogel, 2014). In fact, the maturity of the measurement system is a very complex construct embracing a whole spectrum of sub-constructs including information accessibility, target achievability, information quality, information usefulness and involvement in PI-based benchmarking with other cities (Kroll, 2015a, p. 471).

Within the information systems literature, various models have tried to explain the use of information (Delone and Mclean, 2003; Venkatesh et al., 2003). According to the Technology Acceptance Model and some of its extended versions, there are external variables that impact the usefulness of technology (Venkatesh and Morris, 2000). The Unified Theory of Acceptance and Use of Technology demonstrated various contextual drivers of behavioral intention and actual use of the information system. Among them, the facilitating conditions and the social influence could be applied to the organizational context of public sector performance information. The facilitating conditions encompassed resources, knowledge, and dedicated assistance, while the social influence embraced the support from senior management and the organiza- 
tional support for using information systems (Venkatesh et al., 2003). Importantly, the sub-construct of Information Usefulness has been claimed to be a distinct construct on its own (Adams, Nelson and Todd, 1992; Segars and Grover, 1993), and determining the use of information (Wixom and Todd, 2005). Therefore, there is a need to extract performance information usefulness from the maturity of the measurement system and treat it separately. If the usefulness of performance information affects the use of this kind of information, then the most impactful organizational drivers affecting PI use are expected to influence the usefulness of performance information.

H1: Higher organizational capabilities facilitating PI use (OC) lead to higher usefulness of performance information (PIU).

The Integrated Model made a clear distinction between the quality and usefulness of information (Wixom and Todd, 2005). Thus, this model suggests not treating the quality and usefulness of performance information as one amalgamated construct, but as two separate variables. In general, information quality is a distinct construct on its own (Eppler, 2006), and according to the Integrated Model (Wixom and Todd, 2005), information quality impacts information usefulness. Therefore, it is expected that performance information quality will affect the usefulness of performance information.

H2: Higher performance information quality (PIQ) leads to higher usefulness of performance information (PIU).

Considering that Rana et al. (2015), who built on DeLone and McLean's IS Success Model, found some evidence of the relation between subjective norms and perceived information quality in the environment of an e-government website, it is expected that the organizational drivers of PI use affect the performance information quality.

H3: Higher organizational capabilities facilitating PI use (OC) lead to higher performance information quality (PIQ).

\section{Method and data}

Data from a nationwide survey among Polish local governments (city halls, town halls or municipality offices), conducted between June and August 2017, was used to test the hypothesis. All 2,478 local governments were contacted via official e-mail address and invited to participate in the research on a voluntary basis. In particular, members of the executive boards (e.g., mayors, vice mayors, secretaries) and middle-level managers (heads of the main units in the organizational structure, mainly departments) were requested to fill in the questionnaire. However, in several cases the questionnaires were redirected also to other positions. Such responses were included in the study. The response rate was $20 \%$. After an initial screening, the questionnaires with the lowest completion time were rejected from the final sample due to the very low credibility of the answers. This procedure reduced the final sample to 557 questionnaires representing 466 local governments. The final sample was representative in terms of the number of local governments. Within the sample, female respondents constituted 67\%. Employees aged 30-50 years were the largest group and constituted 
$56 \%$ of the sample; however, $42 \%$ was staff over 50 years old, which suggests that the majority of the population was not young. In terms of occupied positions, most of the respondents $(64.3 \%)$ were in top-level management. Middle-level managers constituted $23.3 \%$, meaning that the respondents from managerial positions constituted $87.7 \%$ of the whole sample. More detailed characteristics are presented in Table 2.

Table 2: Characteristics of the sample

\begin{tabular}{|c|c|c|c|}
\hline & Criteria & $\begin{array}{c}\text { Number of } \\
\text { respondents }\end{array}$ & $\begin{array}{l}\text { Percent of } \\
\text { the sample }\end{array}$ \\
\hline \multirow{3}{*}{ Sex } & Female & 372 & $67 \%$ \\
\hline & Male & 185 & $33 \%$ \\
\hline & $\Sigma$ & 557 & $100 \%$ \\
\hline \multirow{4}{*}{ Age group } & $30-50$ years old & 310 & $56 \%$ \\
\hline & Over 50 years old & 232 & $42 \%$ \\
\hline & Under 30 years old & 15 & $100 \%$ \\
\hline & $\Sigma$ & 557 & $100 \%$ \\
\hline \multirow{5}{*}{$\begin{array}{l}\text { Position of } \\
\text { the respondent }\end{array}$} & Top management & 358 & $64.3 \%$ \\
\hline & Middle level manager & 130 & $23.3 \%$ \\
\hline & Independent position & 43 & $7.7 \%$ \\
\hline & Other & 26 & $4.7 \%$ \\
\hline & $\Sigma$ & 557 & $100 \%$ \\
\hline \multirow{4}{*}{$\begin{array}{l}\text { Size of } \\
\text { the organization }\end{array}$} & More than 100 employees & 77 & $14 \%$ \\
\hline & Between 50-100 employees & 102 & $18 \%$ \\
\hline & Less than 50 employees & 378 & $68 \%$ \\
\hline & $\Sigma$ & 557 & $100 \%$ \\
\hline
\end{tabular}

Source: Author's own work

\subsection{Measures}

\subsubsection{Dependent variable: Performance Information Usefulness}

The usefulness of performance information (PIU) can be defined as the fit of performance information for a particular purpose (Høybye-Mortensen, 2016). There are several types of users of performance information, and few typical purposes of performance information use (Behn, 2003; Van Dooren, Bouckaert and Halligan, 2015). Although IS literature provides more detailed and sophisticated operationalization of information usefulness (Davis, 1989; Adams, Nelson and Todd, 1992), Segars and Grover's (1993) analysis revealed that usefulness embraces only three dimensions, such as 'work more quickly', 'increased productivity', and 'useful'. In accordance with Bjørnholt, Bækgaard and Houlberg (2016), this study applied only the last dimension and adjusted it to the particular purposes of use, namely pertaining to usefulness to learn and to steer and control (Van Dooren, Bouckaert and Halligan, 2015, p. 120). In this study, the usefulness of information for a particular purpose embraces the opinion of the public manager. In accordance with earlier studies (De Lancer-Julnes and Holzer, 
2001; Taylor, 2011), the scale applied in this study used frequency categories. In particular, six categories were considered: never, seldom, occasionally, often, very often, and always (0-5, respectively). Cronbach's $\alpha$ for the PIU scale was 0.85 .

\subsubsection{Development of the independent variables: organizational capabilities facilitating PI use and Performance Information Quality}

Although the variety of drivers of PI use have been described in the literature, the review of empirical research conducted by Kroll (2015) revealed the important organizational capabilities: leadership support, support capacity, innovative culture, goal clarity, and measurement system maturity. However, as already indicated in this article, the maturity of the measurement system is the most important and most complex factor; thus the elements pertaining to information quality and usefulness were excluded from it. This study used PI-based benchmarking with other cities instead of system maturity, as well as other important organizational capabilities indicated by Kroll (2015). The appropriate six point scale was adapted from the Hong Kong Management Capability Index (2016). Cronbach's $\alpha$ for applied OC scale was 0.88.

The quality of performance information (PIQ) can be defined as a set of certain features which performance information has (Bouckaert, 1993). Such a definition is compliant with the view of information quality theory in which information quality is defined as its ability to meet or exceed customer expectations or to meet specifications or requirements (Kahn and Strong, 1998). Within this study, the construct of Performance Information Quality adapted five of Hatry's (2008) criteria. Although the scope of performance information use is very wide (Van Dooren, Bouckaert and Halligan, 2015), within this study it was narrowed to the results of realized and supervised tasks. The questions pertained to the information available to the respondents. The same frequency scale was used for PIU as for PIQ. Cronbach's $\alpha$ for the PIQ scale was 0.89 .

\subsubsection{Control variables}

Previous research on the drivers of PI use (Kroll, 2015b) and contextual factors within TAM (Venkatesh et al., 2003) suggest that several factors should be controlled when investigating the relations between OC, PIQ, and PIU. Among them, the most likely to impact the tested relations are gender, age, professional position, and the size of an organization (Venkatesh et al., 2003; Kroll, 2015b). Thus, within this study, these factors were used as control variables.

\subsection{Data analysis}

All reported analyses and computations were carried out using IBM SPSS version 24. In the initial step of the analysis, the reliability scores based on Cronbach's $\alpha$ for each of the three hypothesized scales were calculated. For all the scales, they indicated very high reliability. Next, OC, PIQ and PIU indicators were computed by summing across items for each scale. For the control variables, the contrasts for the ordered and unordered factors were determined. For the unordered gender factor, the sum to zero 
contrast was used, with -1 and 1 indicating males and females, respectively. For the position factor, also unordered, a deviation contrast comparing each position's mean to overall mean was used. In this case, the last position (meaning 'other position') was excluded. For the two remaining ordered factors (age and number of employees), difference contrasts (reversed Helmert) in which each category (except the first) is compared to the mean effect of all previous categories were used. Additionally, all continuous predictors were zero-centered. In order to test the research hypotheses, linear regression was used.

\section{Results}

In the first part of the analysis, the hypotheses stating that PIU scores should significantly depend on OC and PIQ scores was tested. All control variables and OC were entered into the model in the first step, and PIQ was added in the second step in order to determine the incremental validity of this predictor. No violations of assumptions needed for inference regarding significance and reliability of regression coefficient estimates were detected. The OC and control variables did not explain any significant portion of the variance of the dependent variable $F(9,547)=1.46, p=.161$. The addition of PIQ to the model did result in a significant change of the variance explained, $F(1,546)=104.49, p<.001, \Delta R^{2}=.16$. Thus, the overall model fit also became significant $F(10,546)=12.01, p<.001$, with $17 \%$ of PIU variance explained as indicated by adjusted $R^{2}$. In accordance with the second hypothesis, the quality of performance information was a significant predictor of the usefulness of the performance information. The relationship is positive and of moderate strength. Regression coefficient estimates and the significance test of the final model are presented in Table 3.

Table 3: Linear regression coefficient estimates with significance tests

\begin{tabular}{|c|c|c|c|c|c|c|c|}
\hline Dependent variable: PIU & $B$ & $S E$ & $\beta$ & $t$ & $p$ & $\mathrm{LLCl}$ & ULCI \\
\hline Intercept & 15.66 & 0.38 & & 41.72 & $<0.001$ & 14.92 & 16.39 \\
\hline Gender & -0.14 & 0.16 & -0.03 & -0.88 & 0.377 & -0.47 & 0.18 \\
\hline \multicolumn{8}{|l|}{ Position* } \\
\hline top management vs mean & 0.30 & 0.30 & 0.04 & 0.99 & 0.322 & -0.30 & 0.90 \\
\hline middle management vs mean & -0.66 & 0.34 & -0.08 & -1.96 & 0.051 & -1.33 & 0.00 \\
\hline clerk vs mean & 0.55 & 0.46 & 0.05 & 1.19 & 0.235 & -0.36 & 1.46 \\
\hline \multicolumn{8}{|l|}{ Organization size* } \\
\hline $50-100$ vs $<50$ employees & -0.19 & 0.20 & -0.04 & -0.94 & 0.347 & -0.59 & 0.21 \\
\hline$>100$ vs $(50-100+<50)$ employees & 0.08 & 0.16 & 0.02 & 0.49 & 0.625 & -0.23 & 0.39 \\
\hline \multicolumn{8}{|l|}{ Age $^{*}$} \\
\hline $50-30$ vs $<30$ years old & 0.35 & 0.50 & 0.05 & 0.70 & 0.483 & -0.63 & 1.33 \\
\hline$>50$ vs $(50-30+<30)$ years old & -0.04 & 0.19 & -0.02 & -0.21 & 0.830 & -0.41 & 0.33 \\
\hline Organizational capabilities driving PI use & -0.02 & 0.03 & -0.02 & -0.62 & 0.536 & -0.07 & 0.04 \\
\hline Performance information quality & 0.41 & 0.04 & 0.40 & 10.22 & $<0.001$ & 0.33 & 0.48 \\
\hline
\end{tabular}

Note: $N=557 ; B$ - unstandardized regression coefficient estimates; $\beta$ - standardized regression coefficient estimates; $\mathrm{LLCl}$ and $\mathrm{ULCl}$ - lower and upper values of $95 \%$ confidence intervals of $B$ estimates; ${ }^{*}$ - compared means. 
In the second part of the analysis, the hypothesis stating that OC scores should significantly predict PIQ scores while controlling for all possible confounding variables was tested. All relevant predictors were entered into the model with the Enter method. No violations of the assumptions needed for inference regarding the significance and reliability of the regression coefficient estimates were detected. The overall model fit was very unsatisfactory and insignificant $F(9,547)=0.62, p=0.785$. Coefficients of this model are summarized in Table 4, but since the model did not explain any significant part of the PIQ variance, it will not be discussed further.

Table 4: Linear regression coefficient estimates with significance tests

\begin{tabular}{|c|c|c|c|c|c|c|c|}
\hline Dependent variable: PIQ & $B$ & SE & $\beta$ & $t$ & $p$ & $\mathrm{LLCl}$ & ULC \\
\hline Intercept & 17.10 & 0.40 & & 42.37 & $<0.001$ & 16.31 & 17.89 \\
\hline Gender & -0.21 & 0.18 & -0.05 & -1.17 & 0.243 & -0.55 & 0.14 \\
\hline \multicolumn{8}{|l|}{ Position* } \\
\hline top management vs mean & -0.03 & 0.33 & 0.00 & -0.08 & 0.934 & -0.67 & 0.62 \\
\hline middle management vs mean & -0.07 & 0.36 & -0.01 & -0.18 & 0.856 & -0.78 & 0.65 \\
\hline clerk vs mean & -0.01 & 0.50 & 0.00 & -0.03 & 0.980 & -0.99 & 0.97 \\
\hline \multicolumn{8}{|l|}{ Organization size* } \\
\hline $50-100$ vs $<50$ employees & -0.15 & 0.22 & -0.03 & -0.68 & 0.498 & -0.58 & 0.28 \\
\hline$>100$ vs $(50-100+<50)$ employees & 0.21 & 0.17 & 0.06 & 1.23 & 0.219 & -0.12 & 0.54 \\
\hline \multicolumn{8}{|l|}{$\mathrm{Age}^{*}$} \\
\hline $50-30$ vs $<30$ years old & 0.58 & 0.54 & 0.08 & 1.08 & 0.280 & -0.47 & 1.63 \\
\hline$>50$ vs $(50-30+<30)$ years old & 0.08 & 0.20 & 0.03 & 0.41 & 0.680 & -0.32 & 0.48 \\
\hline Organizational capabilities driving PI use & 0.01 & 0.03 & 0.01 & 0.22 & 0.827 & -0.05 & 0.07 \\
\hline
\end{tabular}

Note: $N=557 ; B$ - unstandardized regression coefficient estimates; $\beta$ - standardized regression coefficient estimates; $\mathrm{LLCl}$ and $\mathrm{ULCl}$ - lower and upper values of $95 \%$ confidence intervals of $B$ estimates; ${ }^{*}$ - compared means.

\section{Discussions}

This study applied theoretical perspectives of information system theory in order to test the relations between the most important organizational capabilities driving performance information use. This helped to provide insight into the potential mediating effects between the organizational drivers of PI use, and thus to better understand the conditions of the use of performance information. The perspective of information systems provides an important theoretical implication which suggests that the quality and usefulness of performance information are two distinct factors. The previous research considered information quality as amalgamated with other components within the construct of measurement system maturity (cf. Kroll, 2015) or as a direct driver of PI use (e.g., Angiola and Bianchi, 2015). The conducted analysis revealed that if the managers and clerks of local government perceive the quality of performance information at their disposal as high, they are more likely to perceive the usefulness of such information as high. These findings not only support treating the quality and usefulness of performance information separately, but also explain why 
measurement of system maturity is deemed the most important driver of PI use. Nevertheless, this study provides an argument to decouple the construct of measurement system maturity in further theorizations and empirical investigations of the drivers of the use of performance information.

Regarding the organizational capabilities that drive the use of performance information, no significant relation to either the quality or usefulness of performance information was found in the case of Polish local governments. This finding supports the results of a small group of studies showing that tested organizational capabilities have no impact on the PI use (cf. Kroll, 2015). Additionally, the conducted research allows the current picture of the relations between the most impactful organizational drivers of PI use indicated by Kroll (2015) to be extended. Neither PIQ nor PIU may be considered as a potential mediator between these organizational drivers and the actual use of performance information because an individual perception of the quality and usefulness of performance information is actually not directly linked to the capabilities of the organization. A possible explanation is that information quality literature makes a clear distinction between the objective and subjective dimensions of the quality of information (Kahn and Strong, 1998; Eppler, 2006). In accordance with this distinction, higher organizational capabilities could result in higher quality of data delivered by performance measurement systems (Niven, 2003; Høybye-Mortensen, 2016), but they do not affect how public managers and clerks perceive the quality and usefulness of performance information at their disposal. The individual skills and knowledge of local government staff might influence the perception of quality and usefulness of performance information as they impact the use of the information and the system (Cucciniello et al., 2015; Kroll and Moynihan, 2015). Profiroiu, Tapardel and Mihescu (2013, p. 198) emphasized the need to increase the awareness of the decision makers to embrace the utilization of project management and strategic management in order to use them as political and managerial tools. In a broader perspective, Hințea, Profiroiu and Țiclău (2015) found that NPM is the least preferred style of public management by local authorities in Romania. In turn, organizational capabilities are more relevant to the adoption phase of performance management instruments (Niven, 2003). Some alternative explanations for the lack of a relationship between OC and PIQ or PIU are also possible. According to Heinrich (1999), the lack of such a relationship could be explained from the perspective of the non-use of performance information. In this case, some managers may perceive performance information as useful and of high quality, regardless of the actual features such information has, because they do not use it. Organizational capabilities, such as innovative culture, leadership support, goal clarity, or good performance results compared to other cities, would not affect the illusion of information quality and usefulness. Possibly, the sample used in this study encompassed cases in which organizational capabilities could have manifested the relations with PIQ and PIU and mixed them with observations of the illusion of information quality and usefulness, hence the overall results yielded insignificant relations. Another possible explanation pertains 
to the differences between the types of use of performance information. If the quality, usefulness and use of the information are linked (Wixom and Todd, 2005), then the information about the results of supervised tasks, actions, and institutions may not be equally useful regarding the type of use. In a similar way, different organizational features are correlated to different uses of performance measures (Folz, Abdelrazek and Chung, 2009), or different components of trust differently affect the internal, hierarchical and public accountability use of performance information (Zhang, Van De Walle and Zhuo, 2016). The conducted study focused on the usefulness in relation to such performance information purposes as learning, steering and controlling, yet they neglected the third option - giving account. Local governments with stronger organizational capabilities might be less afraid of the risks of the 'blame game' (Hood, 2002); hence they are likely to be more interested in public reporting.

\section{Conclusions}

This study used information system theories to refine the understanding of the organizational drivers of PI use in local government in a CEE country. In particular, it showed that performance information quality and usefulness are two distinct factors encapsulated previously within the variable of measurement system maturity. The quality of performance information is an important predictor of its usefulness; therefore, the latter might mediate between its quality and use. In turn, the examined organizational capabilities driving the implementation phase of PI utilization have no direct relationship with either the quality or usefulness of performance information. This suggests important differences between the quality of PI from the perspective of information supply and the quality of PI from the perspective of information users. This conclusion emphasizes the need to decouple the maturity of performance management systems. Additionally, not much research on performance information utilization and its drivers has been reported from CEE countries. This study contributes to the debate on performance information utilization by incorporating the context of a post-communist country.

\section{References:}

1. Adams, D.A., Nelson, R.R. and Todd, P.A., 'Perceived Usefulness, Ease of Use, and Usage of Information Technology: A Replication', 1992, MIS Quarterly, vol. 16, no. 2, pp. 227-247.

2. Angiola, N. and Bianchi, P., 'Public Managers' Skills Development for Effective Performance Management: Empirical Evidence from Italian Local Governments', 2015, Public Management Review, vol. 17, no. 4, pp. 517-542.

3. Beeri, I., Uster, A. and Vigoda-Gadot, E., 'Does Performance Management Relate to Good Governance? A Study of Its Relationship with Citizens' Satisfaction with and Trust in Israeli Local Government', 2018, Public Performance \& Management Review, vol. 42, no. 2, pp. 1-39.

4. Behn, R.D., 'Why Measure Performance? Different Purposes Require Different Measures', 2003, Public Administration Review, vol. 63, no. 5, pp. 586-606. 
5. Bjørnholt, B., Bækgaard, M. and Houlberg, K., 'Does Fiscal Austerity Affect Political Decision-Makers Use and Perception of Performance Information?', 2016, Public Performance and Management Review, vol. 39, no. 3, pp. 560-580.

6. Bouckaert, G. and Balk, W., 'Public Productivity Measurement: Diseases and Cures', 1991, Public Productivity \& Management Review, vol. 15, no. 2, pp. 229-235.

7. Bouckaert, G. and Peters, B.G., 'Measurement Performance: The Achilles' Heel in Administrative Modernization', 2002, Public Performance \& Management Review, vol. 25, no. 4, pp. 359-362.

8. Bouckaert, G., 'Measurement and Meaningful Management', 1993, Public Productivity $\mathcal{E}$ Management Review, vol. 17, no. 1, pp. 31-43.

9. Cepiku, D., Hinna, A., Scarozza, D. and Bonomi Savignon, A., 'Performance Information Use in Public Administration: An Exploratory Study of Determinants and Effects', 2017, Journal of Management \& Governance, vol. 21, no. 4, pp. 963-991.

10. COSO, 'Internal Control - Integrated Framework', Committee of Sponsoring Organizations of the Treadway Commission, 2013, [Online] available at www.coso.org/documents/990025P_Executive_Summary_final_may20_e.pdf, accessed on January 22, 2018.

11. Cucciniello, M., Lapsley, I., Nasi, G. and Pagliari, C., 'Understanding Key Factors Affecting Electronic Medical Record Implementation: A Sociotechnical Approach', 2015, BMC Health Services Research, vol. 15, no. 268, pp. 1-19.

12. Davis, F.D., 'Perceived Usefulness, Perceived Ease of Use, and User Acceptance', 1989, MIS Quarterly, vol. 13, no. 3, pp. 319-339.

13. De Lancer-Julnes, P. and Holzer, M., 'Promoting the Utilization of Performance Measures in Public Organizations: An Empirical Study of Factors Affecting Adoption and Implementation', 2001, Public Administration Review, vol. 61, no. 6, pp. 693-708.

14. Delone, W.H. and Mclean, E.R., 'The DeLone and McLean Model of Information Systems Success: A Ten-Year Update', 2003, Journal of Management Information Systems, vol. 19, no. 4, pp. 9-30.

15. Eppler, M.J., Managing Information Quality, Berlin: Springer, 2006.

16. European Commission, Communication to the Commission, 'Revision of the Internal Control Standards and Underlying Framework - Strengthening Control Effectiveness', Communication SEC(2007)1341, Brussels, 16 October 2007, [Online] available at http://ec.europa.eu/budget/library/biblio/documents/control/sec_2007_1341_en.pdf, accessed on November 13, 2017.

17. Folz, D.H., Abdelrazek, R. and Chung, Y., 'The Adoption, Use, and Impacts of Performance Measures in Medium-Size Cities', 2009, Public Performance \& Management Review, vol. 33, no. 1, pp. 63-87.

18. Fundacja Rozwoju Demokracji Lokalnej, 'Zarządzanie strategiczne w samorządzie lokalnym', Warszawa: Fundacja Rozwoju Demokracji Lokalnej, 2013, [Online] available at http://www.frdl.org.pl/pliki/frdl/zarzadzanie\%20strategiczne/Raport_z_debaty. pdf, accessed on October 2, 2017.

19. Hatry, H., 'Epilogue: The Many Faces of Use', in Van Dooren, W. and Van de Walle, S. (eds.), Performance Information in the Public Sector: How It Is Used, Basingstoke: Palgrave Macmillan, 2008, pp. 227-240. 
20. Heinrich, C.J., 'Do Government Bureaucrats Make Effective Use of Performance Management Information?', 1999, Journal of Public Administration Research and Theory, vol. 9, no. 3, pp. 363-393.

21. Henderson, A.C. and Bromberg, D.E., 'Performance Information Use in Local Government: Monitoring Relationships with Emergency Medical Services Agencies', 2015, Public Performance E Management Review, vol. 39, no. 1, pp. 58-82.

22. Hințea, C.E., Profiroiu, C.M. and Țiclău, T.C., 'Strategic Planning and Public Management Reform: The Case of Romania', 2015, Transylvanian Review of Administrative Sciences, Special Issue, pp. 30-44.

23. Hong Kong Management Association, '2016 Hong Kong Management Capability Index', Hong Kong, 2016, [Online] available at https://www.hkma.org.hk/PDF/HKMCI/ HongKong_MCI_2016.pdf, accessed on May 1, 2018.

24. Hood, C., 'The Risk Game and the Blame Game', 2002, Government and Opposition, vol. 37, no. 1, pp. 15-37.

25. Høybye-Mortensen, M., 'Performance Information in Human Service Organizations: Quality and Usefulness', 2016, Human Service Organizations: Management, Leadership E Governance, vol. 40, no. 5, pp. 486-499.

26. INTOSAI, 'INTOSAI GOV 9100 - Guidelines for Internal Control Standards for the Public Sector', 2004, [Online] available at http://www.issai.org/en_us/site-issai/issai-framework/intosai-gov.htm, accessed on January 22, 2018.

27. Kahn, B.K. and Strong, D.M., 'Product and Service Performance Model for Information Quality: An Update', Proceedings of the 1998 Conference on Information Quality, 1998, [Online] available at http://mitiq.mit.edu/ICIQ/Documents/IQ Conference 1998/ Papers/ProductServicePerformanceModelforIQ.pdf, accessed on May 21, 2018.

28. Kroll, A. and Moynihan, D., 'Does Training Matter? Evidence from Performance Management Reform', 2015, Public Administration Review, vol. 75, no. 3, pp. 411-420.

29. Kroll, A. and Vogel, D., 'The PSM-Leadership Fit: A Model of Performance Information Use', 2014, Public Administration, vol. 92, no. 4, pp. 974-991.

30. Kroll, A., 'Drivers of Performance Information Use: Systematic Literature Review and Directions for Future Research', 2015, Public Performance \& Management Review, vol. 38, no. 3, pp. 459-486.

31. Lee, C. and Clerkin, R.M., 'Exploring the Use of Outcome Measures in Human Service Nonprofits: Combining Agency, Institutional, and Organizational Capacity Perspectives', 2017, Public Performance E Management Review, vol. 40, no. 3, pp. 601-624.

32. Melkers, J. and Willoughby, K., 'Models of Performance-Measurement Use in Local Governments: Understanding Budgeting, Communication, and Lasting Effects', 2005, Public Administration Review, vol. 65, no. 2, pp. 180-190.

33. Moynihan, D.P. and Pandey, S.K., 'The Big Question for Performance Management: Why Do Managers Use Performance Information?', 2010, Journal of Public Administration Research and Theory, vol. 20, no. 4, pp. 849-866.

34. Moynihan, D.P., 'Uncovering the Circumstances of Performance Information Use Findings from an Experiment', 2015, Public Performance $\mathcal{E}$ Management Review, 2015, vol. 39, no. 1, pp. 33-57. 
35. Nemec, J., 'New Public Management and Its Implementation in CEE: What Do We Know and Where Do We Go?', 2010, NISPAcee Journal of Public Administration and Policy, vol. 3, no. 1, pp. 31-52.

36. Nemec, J., Merickova, B. and Ochrana, F., 'Introducing Benchmarking in the Czech Republic and Slovakia: Processes, Problems and Lessons', 2008, Public Management Review, vol. 10, no. 5, pp. 673-684.

37. Niven, P.R., Balanced Scorecard Step-by-Step for Government and Nonprofit Agencies, Hoboken: Wiley, 2003.

38. Pollitt, C., 'Performance Management 40 Years On: A Review. Some Key Decisions and Consequences', 2018, Public Money E Management, vol. 38, no. 3, pp. 167-174.

39. Profiroiu, M.C., Tapardel, A.C. and Mihescu, C., 'Performance Analysis of the Romanian Public Administration', 2013, Transylvanian Review of Administrative Sciences, vol. 40E, pp. 183-200.

40. Rana, N.P., Dwivedi, Y.K., Williams, M.D. and Lal, B., 'Examining the Success of the Online Public Grievance Redressal Systems: An Extension of the IS Success Model', 2015, Information Systems Management, vol. 32, no. 1, pp. 39-59.

41. Segars, A.H. and Grover, V., 'Re-examining Perceived Ease of Use and Usefulness', 1993, MIS Quarterly, vol. 17, no. 4, pp. 517-525.

42. Taylor, J., 'Factors Influencing the Use of Performance Information for Decision Making in Australian State Agencies', 2011, Public Administration, vol. 89, no. 4, pp. 13161334.

43. Van Dooren, W., 'What Makes Organisations Measure? Hypotheses on the Causes and Conditions for Performance Measurement', 2005, Financial Accountability E Management, vol. 21(August), pp. 363-384.

44. Van Dooren, W., Bouckaert, G. and Halligan, J., Performance Management in the Public Sector, $2^{\text {nd }}$ edition, London: Routledge, 2015.

45. Venkatesh, V. and Morris, M.G., 'Why Don't Men Ever Stop to Ask for Directions? Gender, Social Influence, and Their Role in Technology Acceptance and Usage Behavior', 2000, MIS Quarterly, vol. 24, no. 1, pp. 115-139.

46. Venkatesh, V., Morris, M.G., Davis, G.B. and Davis, F.D., 'User Acceptance of Information Technology: Toward a Unified View', 2003, MIS Quarterly, vol. 27, no. 3, pp. 425-478.

47. Wixom, B.H. and Todd, P.A., 'A Theoretical Integration of User Satisfaction and Technology Acceptance', 2005, Information Systems Research, vol. 16, no. 1, pp. 85-102.

48. Zhang, H., Van De Walle, S. and Zhuo, Y., 'Does Trust in the Performance Measurement Organization Influence How Public Managers Use Performance Information?', 2016, Public Performance E Management Review, vol. 40, no. 2, pp. 409-430. 


\section{TRANSYLVANIAN REVIEW}

Mojca BIŠČAK

Jože BENČINA

The Impact of HRM Practices on the Performance of Municipalities.

The Case of Slovenia

Oana Maria BLAGA

Răzvan Mircea CHERECHEȘ

Cătălin Ovidiu BABA

A Community-Based Intervention for Increasing Access

to Health Information in Rural Settings

Emil BOC

The Development of Participatory Budgeting Processes in Cluj-Napoca

Andrei CHIRCĂ

Dan Tudor LAZĂR

Students' Visitors - Among the Unexplored Types of Local Tourism?

Min-Hyu KIM

65 Factors Influencing the Propensity to Contract Out Health and Human Services in Response to Government Cutbacks: Evidence from US Counties

Mateusz LEWANDOWSKI

85 Organizational Drivers of Performance Information Use:

The Perspective of Polish Local Governments

Romea MANOJLOVIĆ TOMAN

Goranka LALIĆ NOVAK

100 The (Lack Of) Demand for Performance Information by the Croatian Parliament Oleksiy POLUNIN

116 The Case of Ukrainian Corruption: Phenomenology and Psychological Insides 